\title{
Differential involvement of adrenal and gonadal steroids in anterior and intermediate pituitary pro-opiomelanocortin mRNA expression induced by the endogenous benzodiazepine, octadecaneuropeptide, in adult male rats
}

\author{
L Givalois ${ }^{1}, \mathbf{S}$ Li $^{2}$ and $\mathbf{G}$ Pelletier ${ }^{2}$ \\ ${ }^{1}$ Cerebral Plasticity Laboratory, EP-628 CNRS, Montpellier II University, Eugène Bataillon Place, 34095 Montpellier, France \\ ${ }^{2}$ Molecular Endocrinology Laboratory, CHUL Research Center of Laval University, 2705 Laurier Boulevard, St Foy, Quebec G1V 4G2, Canada \\ (Requests for offprints should be addressed to L Givalois, Laboratoire de Plasticité Cérébrale, EP628-CNRS, Université Montpellier II, Place E Bataillon, \\ F-34095 Montpellier, France)
}

\begin{abstract}
The involvement of the endogenous benzodiazepine, octadecaneuropeptide (ODN), in the regulation of proopiomelanocortin (POMC) mRNA expression at the pituitary level, and the influence of adrenal and gonadal steroids, have been studied using a quantitative in situ hybridization technique. I.c.v. injection of ODN $(4 \mu \mathrm{g} /$ $\mathrm{kg}$ ) in sham-operated rats induced a 17 and $7 \%$ decrease in the POMC mRNA expression in anterior and intermediate pituitary lobes respectively. To determine the reciprocal involvement of adrenal and gonadal steroids in this regulation, animals were adrenalectomized and/or castrated. Adrenalectomy significantly increased POMC mRNA expression by $48 \%$ at the anterior pituitary level, but induced a $10 \%$ decrease of hybridization signal at the intermediate pituitary lobe (vs control sham-operated). Adrenal ablation reversed the effect induced by ODN and increased POMC mRNA expression at the anterior and intermediate pituitary levels by 60 and 10\% respectively, compared with control sham-operated. By contrast, cas-
\end{abstract}

tration, which produced a decrease in POMC mRNA in the anterior pituitary and an increase in the intermediate lobe, did not modify the negative influence of ODN observed in sham-operated animals. When rats were adrenalectomized and castrated, the adrenalectomy influence was predominant at the anterior pituitary level, since ODN increased significantly the hybridization signal (+68\% vs control sham-operated), while the castration influence was predominant at the intermediate pituitary level, since ODN induced an 11\% decrease in POMC mRNA signal compared with control sham-operated. These studies indicate that, in vivo, the decrease in POMC mRNA expression in the anterior and intermediate pituitary induced by an endogenous benzodiazepine is differently modulated by adrenal and gonadal steroids, with a predominant influence of adrenal steroids at the anterior pituitary level and gonadal steroids at the intermediate pituitary level.

Journal of Endocrinology (1999) 161, 307-316

\section{Introduction}

In the pituitary gland, pro-opiomelanocortin (POMC) is predominantly expressed in corticotropic cells of the pars distalis or anterior pituitary (AP) and in melanotropic cells of the pars intermedia or intermediate pituitary (IP). POMC is also expressed in a discrete population of neurons localized in the arcuate nucleus (AN) of the basal hypothalamus (reviewed in Pelletier (1993)). The hypothalamic peptides, corticotropin-releasing hormone $(\mathrm{CRH})$ and arginine vasopressin, have a major function in stimulating adrenocorticotropic hormone and $\beta$-endorphin release from the AP (Vale et al. 1981, Assenmacher et al. 1995), as well as inducing $\beta$-endorphin and $\alpha$-melanocyte stimulating hormone release from the IP (Saland et al. 1988, Muller \& Von Werder 1991). These hormones, derived from POMC, are considered as stress-related molecules and are involved in the hypothalamuspituitary-adrenocortical (HPA) axis response in a variety of circumstances, and thus in the maintenance of homeostasis (reviewed in Whitnall 1993).

The melanotropic cells of the IP are directly innervated by monoaminergic (Björklund et al. 1973) and gammaaminobutyric acid (GABA)ergic neurons located in the central nervous system (Vuillez et al. 1987), while the AP corticotropic cells have been shown to contain GABA receptors (Berman et al. 1994). These observations have suggested that GABA might be directly involved in the regulation of POMC mRNA expression at both the AP and IP levels. It is well known that GABA can interact with two distinct classes of receptors, termed GABAA and $G A B A B$ receptor complexes, which differ in their 
pharmacological, electrophysiological and biochemical properties. The GABAA receptor complex has been shown to contain five major binding sites, for GABA, benzodiazepines (BZD), barbiturates, picrotoxin (specific antagonist) and steroids. GABA, as well as GABAA agonists and other activators of GABAA receptors such as BZD and barbiturates, has been shown to decrease mRNA levels in POMC melanotropic cells (Jegou et al. 1991, Garcia-de-Yebenes \& Pelletier 1994). The presence of GABAA receptors in melanotropic and corticotropic cells has been reported (Louiset et al. 1992, Berman et al. 1994).

Anxiety and depression, terms used by behavioral scientists and clinicians, can be states induced in part by release of stress hormones. Some anxiolytic agents have been developed to reduce unwanted behavioral traits. Such agents include BZDs, which may act to reduce the anxiety and depressive states by interacting within the central nervous system to modulate the levels of stress hormones including corticotropin releasing factor (Grigoriadis et al. 1989). In rat brain, an endogenous BZD polypeptide with high affinity for diazepam-binding sites, named diazepam-binding inhibitor (DBI) has been described (Guidotti et al. 1983). This polypeptide is located in the central nervous system in glial cells and neurons (Alho et al. 1985). In some neurons, GABA has been co-localized with DBI (Costa et al. 1986) and at least two different processing products, $\mathrm{DBI}_{35-50}$ or octadecaneuropeptide $(\mathrm{ODN})$ and $\mathrm{DBI}_{17-50}$ or triakontatetraneuropeptide (Alho et al. 1990). I.c.v. injection of DBI elicits pro-conflict responses and antagonizes the anti-conflict and anxiolytic properties of the GABA/BZD complex or GABAA receptor (Ferrero et al. 1984, Kavaliers \& Hirst 1986). ODN markedly reduces the effects of GABA on hormonal release (Tonon et al. 1989) and totally abolishes the chloride current induced by GABA (Louiset et al. 1993). In man, there is a positive correlation between cerebrospinal fluid concentrations of DBI and CRH in depressed patients, suggesting that DBI and processing products might play a role in the release of $\mathrm{CRH}$ and the activation of the HPA axis response to stress, probably via GABAA receptors (Roy et al. 1989). Recently, we have clearly demonstrated that, in vivo, the endogenous BZD, ODN, via an activation of the BZD sites of GABAA receptor, negatively modulates $\mathrm{CRH}$ neuronal activity and that this modulation can be negatively or positively influenced by central and peripheral steroids (Givalois et al. 1998a). Moreover, ODN modulation of the HPA axis activity seems to involve adrenal and/or gonadal factor(s) other than glucocorticoids (Givalois et al. 1998). At the pituitary level, the central injection of ODN produces an inhibition of POMC gene expression at the IP level as well as at the AN level (Garcia-de-Yebenes et al. 1997). These effects on the POMC mRNA expression were completely reversed by concomitant administration of the GABAA receptor antagonist, picrotoxin, and seem to be modulated allosterically by neurosteroids (Garcia-de-Yebenes et al. 1997).

In this study, to further examine the possible role of peripheral steroids in the modulation of POMC gene expression at the AP and IP levels induced by the endozepine ODN, we investigated the impact of adrenalectomy $(\mathrm{ADX})$ and/or castration $(\mathrm{CX})$ on the POMC mRNA levels in the corticotropic and melanotropic cells following ODN i.c.v. injection.

\section{Materials and Methods}

\section{Animals}

Fifty adult male Sprague-Dawley rats (Charles Rivers Canada Inc., Montreal, Quebec, Canada) weighing $225-250 \mathrm{~g}$ at the beginning of the experiment were housed under constant temperature $\left(21 \pm 1^{\circ} \mathrm{C}\right)$ and lighting (lights on from 0600 to $2000 \mathrm{~h}$ ) regimens. They had free access to standard rat chow, and tap water for sham-operated and CX rats or isotonic water $(0 \cdot 9 \% \mathrm{NaCl})$ for ADX rats.

\section{Experimental procedures}

The drug used was the endogenous BZD receptor ligand, ODN (Peninsula Laboratories, Belmont, CA, USA), which was stereotaxically injected into the left lateral ventricle at a dose of $4 \mu \mathrm{g} / \mathrm{kg}$ and at a rate of $2 \mu \mathrm{l} / \mathrm{min}$ in a total volume of $20 \mu \mathrm{l}$ (Li \& Pelletier 1996). In order to study the involvement of adrenal and sexual steroids in the variation of POMC mRNA expression induced by ODN, the 50 animals were divided into four groups. Five days before experimentation the animals underwent ADX $(n=12), \mathrm{CX}(n=12)$ or ADX and CX (ADX/CX; $n=14)$; sham-operated animals $(n=12)$ served as controls. On the day of the experiment, each group was divided into two, and four groups received an i.c.v. injection of ODN $(4 \mu \mathrm{g} / \mathrm{kg})$, while the other four groups (control groups) received an i.c.v. injection of vehicle $(0.9 \% \mathrm{NaCl})$.

Four hours after i.c.v. injection of either vehicle or ODN, the animals were deeply anesthetized with an i.m. injection of $0.2 \mathrm{ml}$ of a mixture of ketamine hydrochloride $(80 \mathrm{mg} / \mathrm{kg})$ and xylazine $(10 \mathrm{mg} / \mathrm{kg})$ and then rapidly perfused transcardially with $4 \%$ paraformaldehyde in $0 \cdot 2 \mathrm{M}$ phosphate buffer. The pituitaries were removed and postfixed in the same fixative for $4 \mathrm{~h}$ at $4{ }^{\circ} \mathrm{C}$, and then placed in $15 \%$ sucrose in $0.2 \mathrm{M}$ phosphate buffer overnight at $4{ }^{\circ} \mathrm{C}$. Thereafter, the tissues were quickly frozen in isopentane chilled in liquid nitrogen. The frozen pituitaries were mounted on a cryostat (Leitz, Montreal, Quebec, Canada) and serially cut into $10 \mu \mathrm{m}$ coronal sections. The pituitary sections were mounted on gelatinand poly-L-lysine-coated glass slides and kept at $-80{ }^{\circ} \mathrm{C}$ until use. Hybridization histochemical localization of 
POMC transcripts was carried out using a ${ }^{35}$ S-labeled oligoprobe, as described below.

\section{Preparation of the POMC probe}

The probe used for in situ hybridization was a $\left[{ }^{35} \mathrm{~S}\right] \mathrm{dATP}-$ labeled 30 bases oligonucleotide synthesized in our laboratory, complementary to the POMC-coding region of the rat complementary DNA (bases 297-324) (Garcia-deYebenes et al. 1997). The sequence corresponding to the probe is: 5'-CTT-GCC-CCA-GCG-GAA-GTGCTC-CAT-GGA-GTA-3'. Radioactive oligoprobe was obtained using the terminal deoxynucleotidyl transferase (TdT, Pharmacia, Biotech Inc., Baie d'Urfé, Quebec, Canada) technique, by incubation of $300 \mathrm{ng}$ oligonucleotide template in $5 \mu \mathrm{l}$ buffer 'One for all' $10 \times$ (Pharmacia), in $2 \mu \mathrm{l}$ TdT $(25 \mathrm{U} / \mu \mathrm{l}), 4 \mu \mathrm{l}\left[\alpha_{-}{ }^{35} \mathrm{~S}\right] \mathrm{ATP}$ $(50 \mu \mathrm{Ci}$; Dupont NEN, Boston, MA, USA), $37 \cdot 5 \mu \mathrm{l}$ Diethyl Pyrocarbonate sterile water for $90 \mathrm{~min}$ at $37^{\circ} \mathrm{C}$. In order to reduce background, unincorporated nucleotides were removed using a Microspin column (Pharmacia).

\section{In situ hybridization with oligoprobe}

Some serial sections from each group were treated with ribonuclease A (RNAse A; $100 \mu \mathrm{g} / \mathrm{ml}$; Pharmacia) for $45 \mathrm{~min}$ at $37^{\circ} \mathrm{C}$ before hybridization and served as negative controls. Pituitary sections mounted onto poly-Llysine-coated slides were rinsed in $2 \times$ standard saline citrate $(2 \times$ SSC; $0.15 \mathrm{M} \mathrm{NaCl}, 0.015 \mathrm{M}$ sodium citrate, $\mathrm{pH} 7 \cdot 0$ ) for $10 \mathrm{~min}$ at room temperature and treated for 15 min with $0 \cdot 1 \%$ Triton (BDH Inc., Toronto, Ontario, Canada) at room temperature. Thereafter, the pituitary sections were rinsed in $2 \times$ SSC and prehybridized at room temperature in a humid chamber for $2 \mathrm{~h}$ in $450 \mu \mathrm{l} /$ slide of prehybridization buffer containing $50 \%$ formamide, $5 \times$ SSPE $(1 \times$ SSPE being $0 \cdot 1 \mathrm{M} \mathrm{NaCl}, 10 \mathrm{mM}$ $\mathrm{NaH}_{2} \mathrm{PO}_{4}, \quad \mathrm{pH} \quad 7 \cdot 4, \quad 1 \mathrm{mM}$ EDTA), $5 \times$ Denhart's buffer, $200 \mathrm{mg} / \mathrm{ml}$ denatured salmon testis DNA (Sigma Chemical Co., St Louis, MO, USA), $200 \mu \mathrm{g} / \mathrm{ml}$ yeast tRNA, $2 \mu \mathrm{g} / \mathrm{ml}$ poly A (Boehringer-Mannheim Canada, Dorval, Quebec, Canada) and 4\% dextran sulfate. After prehybridization treatment, $100 \mu$ hybridization mixture (prehybridization buffer containing in addition $10 \mathrm{mM}$ dithiothreitol and ${ }^{35} \mathrm{~S}$-oligoprobe at a concentration of $10 \times 10^{6}$ c.p.m. $/ \mathrm{ml}$ ) were spotted on each slide, sealed under a coverslip, and incubated at $37^{\circ} \mathrm{C}$ overnight $(15-20 \mathrm{~h})$ in a humid chamber. After hybridization, coverslips were removed and slides rinsed in descending concentrations of SSC $(2 \times, 1 \times$ and $0.5 \times)$ for $30 \mathrm{~min}$ each at room temperature, washed in $0.5 \times$ SSC for $1 \mathrm{~h}$ at $37^{\circ} \mathrm{C}$ and finally for $30 \mathrm{~min}$ at room temperature in $0.5 \times$ SSC. After the posthybridization treatments, the sections were dehydrated and exposed to Kodak X-Omat films (Eastman Kodak, Rochester, NY, USA) for $5 \mathrm{~h}$ for the IP lobe and overnight for the AP lobe, before being coated with liquid photographic emulsion (Kodak-NTB2; diluted 1:1 with water). Slides were exposed for 1 day, developed in Dektol developer (Kodak) for $2 \mathrm{~min}$ and fixed in rapid fixer (Kodak) for $4 \mathrm{~min}$. Thereafter, tissues were rinsed in running water for $30 \mathrm{~min}$, counterstained with thionin $(0 \cdot 25 \%)$ and rapidly dehydrated through graded concentrations of ethanol, cleared in toluene and coverslipped with Permount (Fisher Scientific Co. Ltd, Ottawa, Ontario, Canada).

\section{Quantitative analysis}

Semiquantitative analysis of hybridization signals for POMC mRNA was carried out on autoradiographic films differentially exposed to show differences between IP and AP lobes, using a Sony CCD XC-77 video camera with high resolution $(570(\mathrm{H}) \times 485(\mathrm{~V})$ TV lines) coupled to a Macintosh computer (Power PC 7500/100) and Image Software (version 1.60 non-FPU, W Rasband, NIH, Bethesda, MA, USA). The optical density (OD) of the hybridization signal was measured under brightfield illumination. The images of the pituitaries were digitized and subjected to densitometric analysis, yielding measurements of integrated OD (area of different lobes $\times$ average OD).

\section{Statistical analysis}

Quantitative data are presented as mean \pm S.E.M. The mean and S.E.M. were calculated from six to eight measurements per animals performed in serial sections of respective pituitaries. Comparison of the mRNA levels between treatment groups was performed by an ANOVA (Statview 4.5 ANOVA) (Rivest \& Laflamme 1995, Givalois et al. 1997); $P<0 \cdot 05$ was considered as statistically significant.

\section{Bioethics}

Each rat was used for experimentation only once, and all protocols were approved by the Laval University's Animal Welfare Committee.

\section{Results}

As shown by light microscope darkfield micrographs in Fig. 1, a very intense labeling obtained after in situ hybridization with the ${ }^{35}$ S-labeled POMC oligoprobe was observed in the IP lobe, while a much weaker hybridization signal corresponding to the labeling of the corticotropic cells occurred in the AP. The posterior pituitary (PP) lobe remained completely unlabeled. Pretreatment with RNAse A, as negative control, completely prevented 

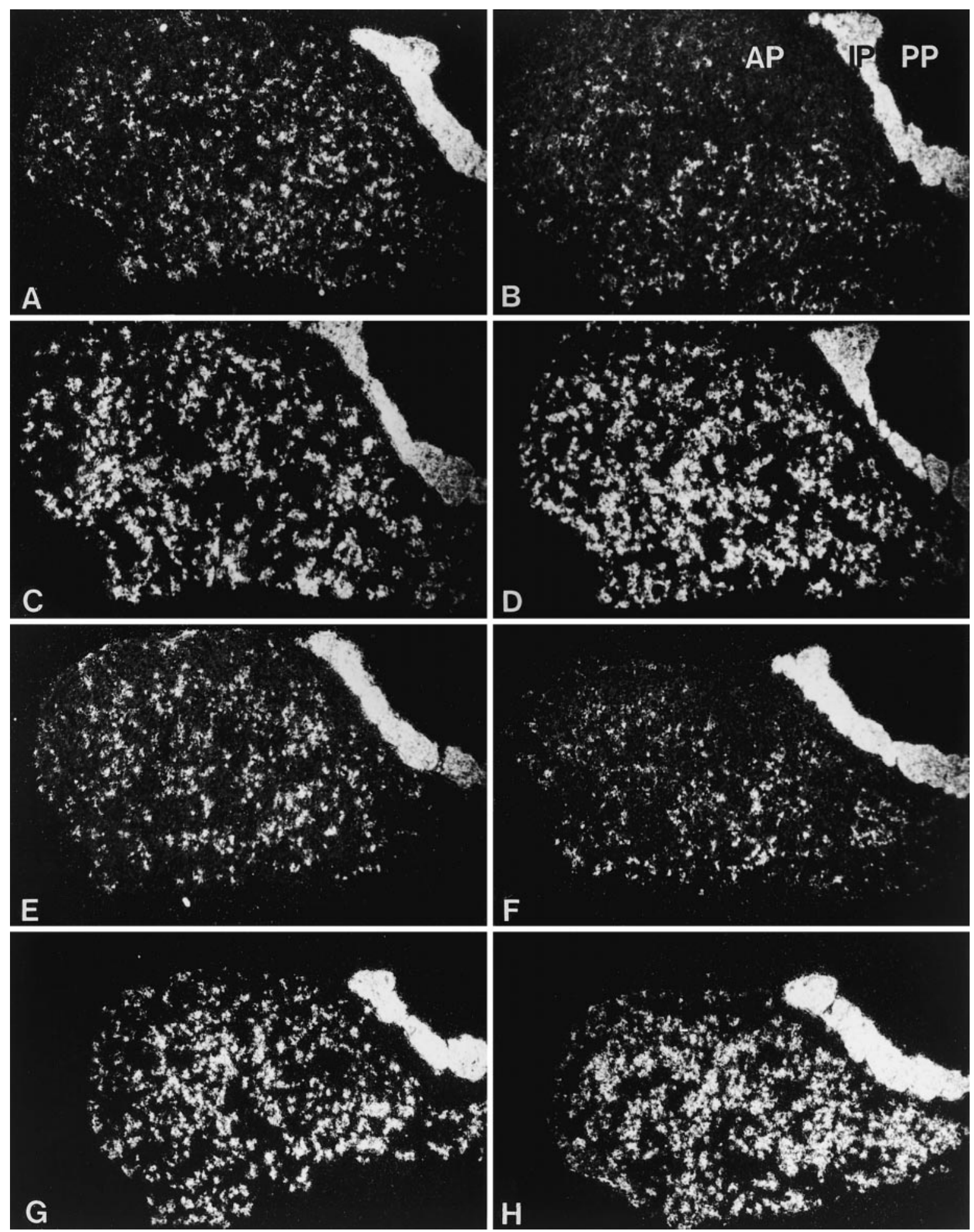

Figure 1 Representative examples illustrating POMC mRNA expression in the IP and AP lobes, $4 \mathrm{~h}$ after i.c.v. administration of vehicle (control rats; left panels) or ODN (right panels), in sham-operated (panels A and B), ADX (C and D), CX (E and F) and $\mathrm{ADX} / \mathrm{CX}(\mathrm{G}$ and $\mathrm{H})$ rats. These depict darkfield photomicrographs of dipped autoradiographs of hybridized $10 \mu \mathrm{m}$ pituitary sections with the ${ }^{35}$ S-labeled specific oligoprobe to detect POMC mRNA. Note the absence of hybridization signal in the PP lobe. (Magnification $\times$ 40.) 

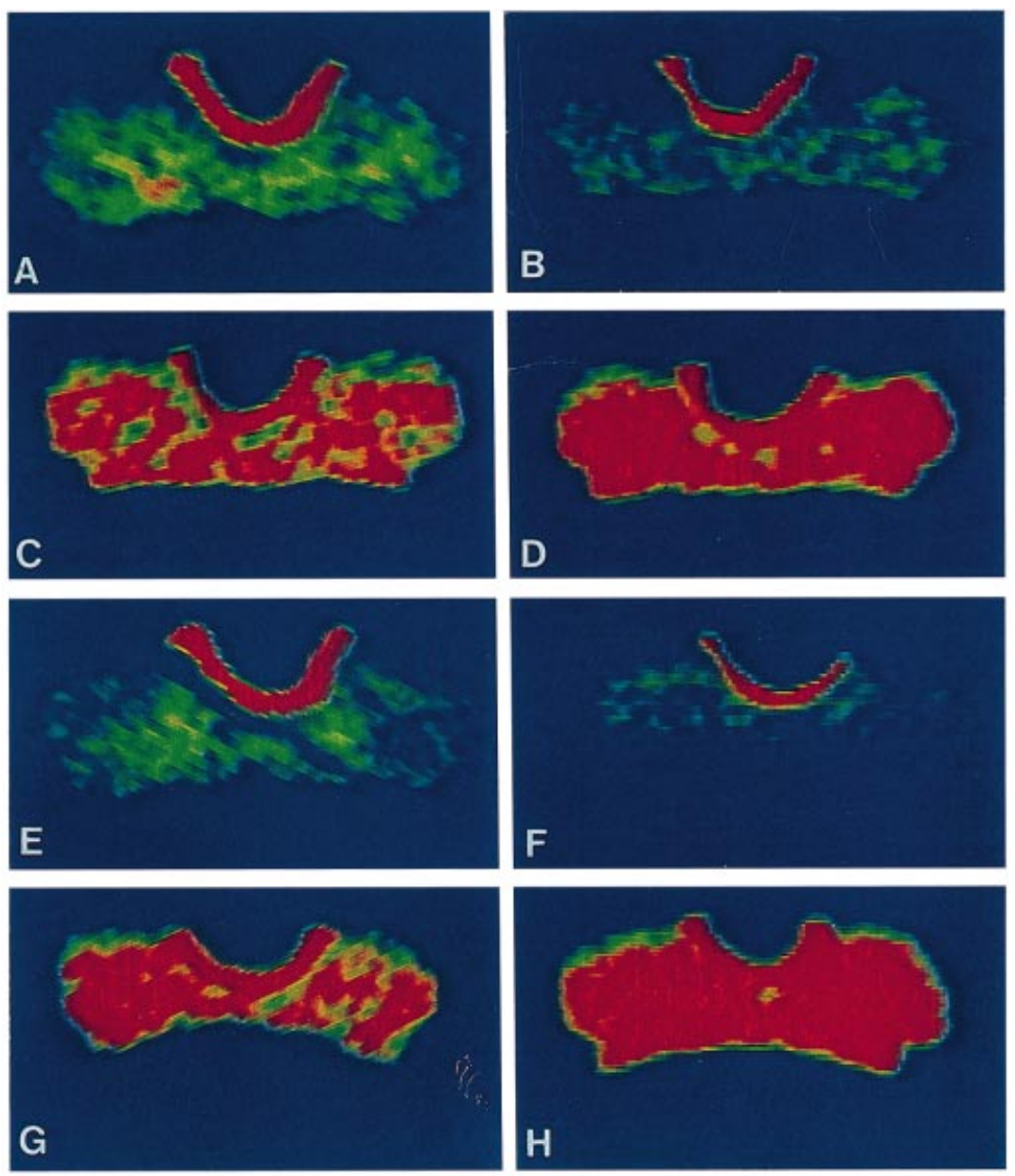

Figure 2 Digitized autoradiographs of representative POMC mRNA expression in sham-operated (panels $\mathrm{A}$ and $\mathrm{B}), \mathrm{ADX}(\mathrm{C}$ and $\mathrm{D}), \mathrm{CX}(\mathrm{E}$ and $\mathrm{F})$ and $\mathrm{ADX} / \mathrm{CX}(\mathrm{G}$ and $\mathrm{H})$ rats, $4 \mathrm{~h}$ after i.c.v. injection of vehicle (left panels) or ODN $(4 \mu \mathrm{g} / \mathrm{kg}$; right panels) at the AP level. Autoradiographic film was exposed overnight to detect POMC variations at the AP level. The intensity of the in situ hybridization signal is represented by rainbow colors with blue corresponding to low, green to medium, and red to high OD.

(Magnification $\times 25$.)

any labeling following hybridization with the labeled oligoprobe (data not shown).

\section{AP lobe}

To accurately analyze POMC mRNA levels in the AP and IP in the same sections, autoradiographic films were exposed overnight and for $5 \mathrm{~h}$ respectively. The respective involvement of adrenal and testis in the variations of POMC mRNA expression in response to ODN are presented in Figs 1-5. At the AP level (Figs 2 and 3), the i.c.v. injection of ODN in sham-operated rats decreased $(-17 \% ; P<0 \cdot 01$ vs control sham-operated) the in situ hybridization signal measured $4 \mathrm{~h}$ later
(Fig. 2A and B). ADX significantly increased by $48 \%$ $(P<0 \cdot 01$ vs control sham-operated) the basal POMC mRNA levels (Fig. 2C). In these animals, the effect of ODN was reversed, since a $60 \% \quad(P<0 \cdot 01)$ increase compared with control sham-operated and an $8 \%$ $(P<0 \cdot 01)$ increase compared with control ADX rats were observed (Fig. 2D). In contrast to ADX, CX decreased basal POMC mRNA expression ( $-15 \%$; $P<0 \cdot 01$ vs control sham-operated) and did not modify the negative response to ODN which appeared very similar to that observed in sham-operated animals (Fig. $2 \mathrm{E}$ and F). Finally, ADX and CX induced a significant increase of basal POMC gene expression at the AP level $(+53 \% ; P<0.01$ vs control sham-operated), which was 


\section{Pars distalis}

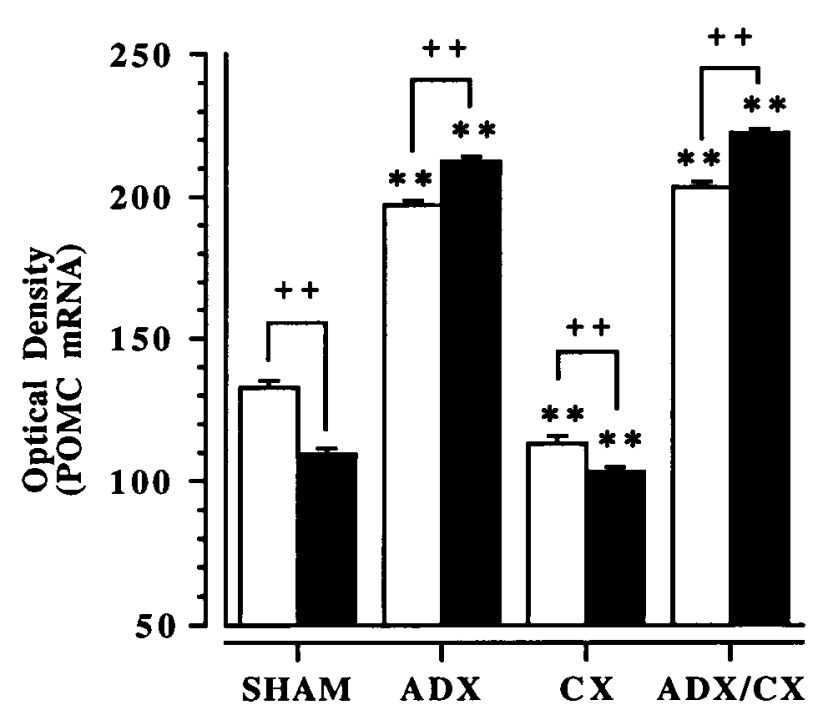

Figure 3 Effects of i.c.v. vehicle (open bars) or ODN (filled bars) injection on POMC mRNA expression in the AP cells of the shamoperated (SHAM), ADX, CX and ADX/CX rats. Autoradiographic film was exposed overnight at $4{ }^{\circ} \mathrm{C}$. Results are expressed as the means \pm S.E.M. with $n=5$ in each groups of rats. ${ }^{* *} P<0 \cdot 01$ vs control sham-operated rats and $++P<0 \cdot 01$ vs control rats in each group.

more marked, but not significantly different from that observed after ADX alone (Fig. 2G). ODN injection into $\mathrm{ADX} / \mathrm{CX}$ rats induced an increase of POMC mRNA levels in the AP $(+68 \% ; P<0.01$ vs control sham-operated, and $+9 \%$; $P<0 \cdot 01$ vs control ADX/ $\mathrm{CX})$, which was comparable to the increase observed in animals which were only ADX (Fig. 2D and H).

\section{IP lobe}

At the IP level (Figs 4 and 5), as already reported (Garcia-de-Yebenes \& Pelletier 1994), the acute i.c.v. administration of ODN (4 h before killing) induced a significant decrease of POMC mRNA expression $(-7 \%$; $P<0 \cdot 05$ vs control sham-operated) (Fig. $4 \mathrm{~A}$ and B). ADX performed 5 days before the experiment produced a $10 \%$ $(P<0.01$ vs control sham-operated) decrease in the hybridization signal (Fig. 4C). The injection of ODN to ADX animals not only did not produce a decrease in POMC mRNA levels, but rather resulted in a significant increase of $10 \%(P<0 \cdot 01)$ over the levels measured in control ADX animals (Fig. 4D). In contrast, CX that increased basal POMC mRNA expression $(+6 \% ; P<0 \cdot 05$ vs control sham-operated) did not modify the response to ODN, which produced an inhibitory influence on POMC mRNA levels similar to that observed in shamoperated animals (the decrease being 13\% compared with $7 \%$ for the sham-operated animals) (Fig. 4E and F). Finally, the combination of $\mathrm{ADX}$ and $\mathrm{CX}$ aimed at eliminating the production of steroid hormones resulted in a significant increase in the POMC mRNA hybridization signal (Fig. 4G) which was not different from the increase obtained after CX. In ADX/CX rats, ODN administration (Fig. $4 \mathrm{H}$ ) was shown to induce an $11 \%$ decrease $(P<0 \cdot 01$ vs control ADX/CX) in the POMC mRNA level, which was intermediate between levels obtained after CX (Fig. 4D) and which was not different from that observed in control sham-operated rats (Fig. 4B).

\section{Discussion}

The negative modulation of POMC mRNA in both melanotropic and corticotropic cells by GABAA receptor complex ligands such BZD and barbiturates has already been demonstrated. The present results obtained in intact rats confirm these different studies (Loeffer et al. 1986, Jegou et al. 1991, Garcia-de-Yebenes \& Pelletier 1994, Garcia-de-Yebenes et al. 1997). However, on the basis of results obtained on the behavior of rats, it has been suggested that ODN could act as an inverse agonist of central type BZD receptors or GABAA receptor complex (Ferrero et al. 1986). In the present study, in agreement with previous works (Li \& Pelletier 1995, Garcia-deYebenes et al. 1997, Li et al. 1997a,b, Givalois et al. 1998a), we clearly demonstrate that ODN exerts an agonistic influence on GABAA receptors. This apparent discrepancy might be explained by the differences in the experimental conditions or in the doses used, as well as in the parameters which have been measured.

The present results did not provide precise information about the site(s) of action of ODN on POMC mRNA expression. DBI and DBI-related peptides have been shown to be produced by glial cells (Tonon et al. 1990, Tong et al. 1991, Malagon et al. 1993). Thus it might be suggested that DBI-related peptides, including ODN released from glial cells, can reach $\mathrm{CRH}$ neurons at the hypothalamic level in a paracrine way and directly interact with these neurons, which have been shown to contain GABAA receptors (Fenelon \& Herbison 1995), to modulate POMC mRNA expression at the pituitary level. We have already shown that ODN negatively modulates $\mathrm{CRH}$ neuronal activity (Givalois et al. 1998a), but since GABAA receptors are present at the pituitary level (Louiset et al. 1992, Berman et al. 1994), a direct action of ODN, which could reach the pituitary via a diffusion of the peptide into the cerebrospinal fluid or via the short portal veins, should also be considered. On the other hand, the possibility that the effect of ODN on the IP might be mediated by modification of hypothalamic neuronal activity such as dopaminergic neurons which reach the melanotropic cells through the tuberohypophyseal dopaminergic tract, and which negatively control POMC mRNA expression (Hollt et al. 1982, Chen et al. 1983, Saland et al. 1988) cannot be disregarded. 

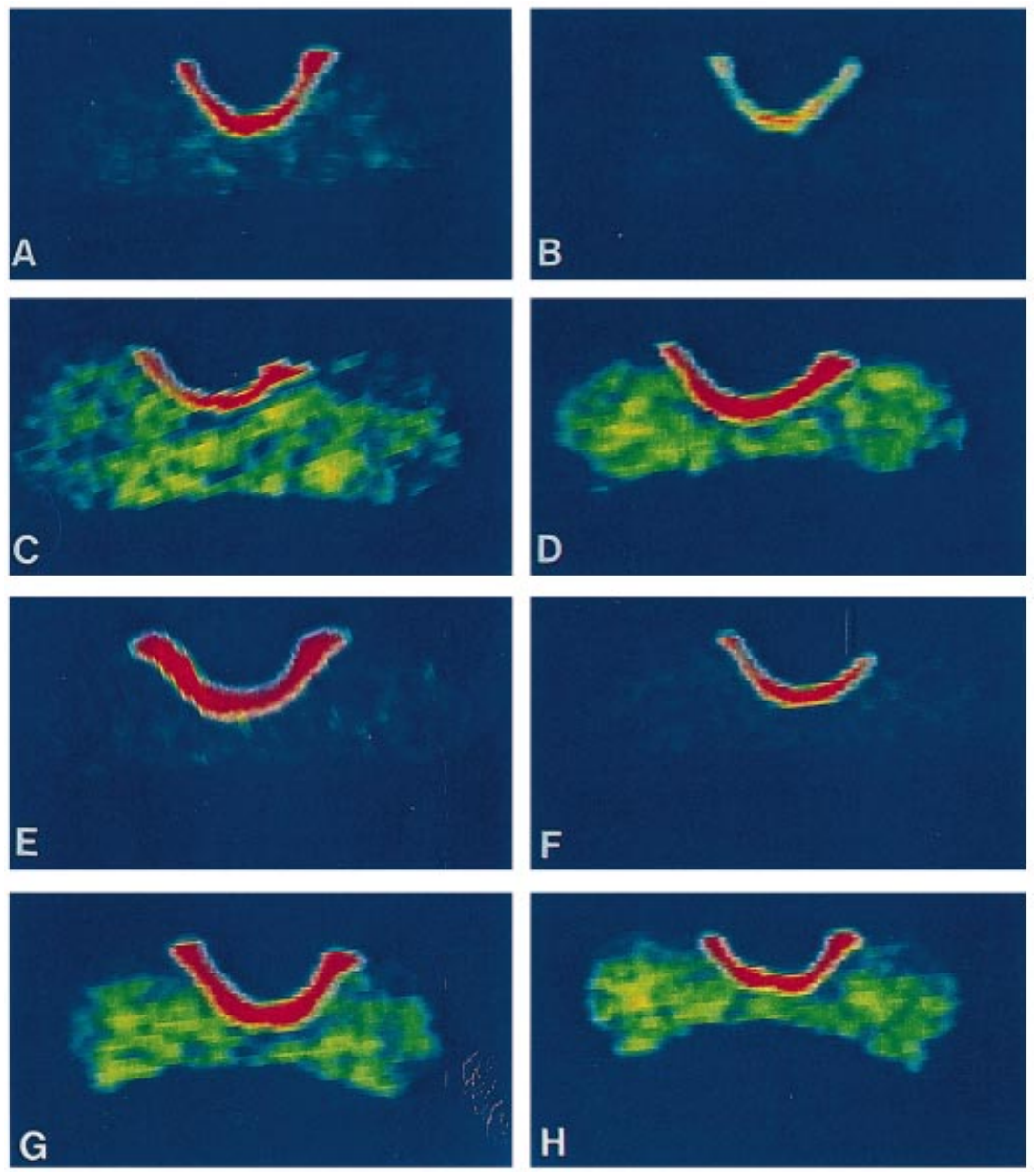

Figure 4 Digitized autoradiographs of representative POMC mRNA expression in sham-operated (panels A and B), ADX (C and D), CX (E and F) and ADX/CX (G and H) rats, $4 \mathrm{~h}$ after i.c.v. injection of vehicle (left panels) or ODN $(4 \mu \mathrm{g} / \mathrm{kg}$; right panels) at the IP level. Autoradiographic film was exposed overnight to detect POMC variations at the IP level. The intensity of the in situ hybridization signal is represented by rainbow colors with blue corresponding to low, green to medium, and red to high OD. (Magnification $\times 25$.)

In order to study the role of circulating steroids and the respective involvement of the adrenals and testis in the effect of ODN on the POMC mRNA expression, we have evaluated the influence of ADX, CX and the combination of both treatments on the ODN-induced response of POMC mRNA expression at the IP and AP levels. We demonstrated that the direct and/or indirect effect induced by the endogenous BZD on the POMC mRNA expression was influenced by adrenal and gonadal factors at the AP and IP levels respectively.

ADX, which increases the HPA axis activity at the central level (Sawchenko 1987, Spinedi et al. 1991, Givalois et al. 1998a), reversed the effects of ODN on POMC mRNA expression, since the administration of ODN to ADX animals slightly increased mRNA levels instead of inducing the expected decrease in the hybrid- ization signal observed at the AP and IP levels in control sham-operated rats. In fact, in ADX animals, which are deprived of adrenal hormones, we find, as previously reported with CRH mRNA expression (Givalois et al. 1998a), that ODN is acting as an inverse agonist on POMC mRNA at the AP and also at the IP lobe. By contrast, $\mathrm{CX}$, which decreased at the AP level and increased at the IP level the basal POMC mRNA expression, did not modify the negative influence of ODN on the POMC mRNA hybridization signal. In fact, this endozepine amplified the response to ODN in the IP. Moreover, in accordance with our results on $\mathrm{CRH}$ mRNA expression (Givalois et al. 1998a), the involvement of the adrenal in the action of ODN seems to be predominant at the AP level on corticotropic cells, since in ADX/CX animals ODN induced a significant increase in 


\section{Pars intermedia}

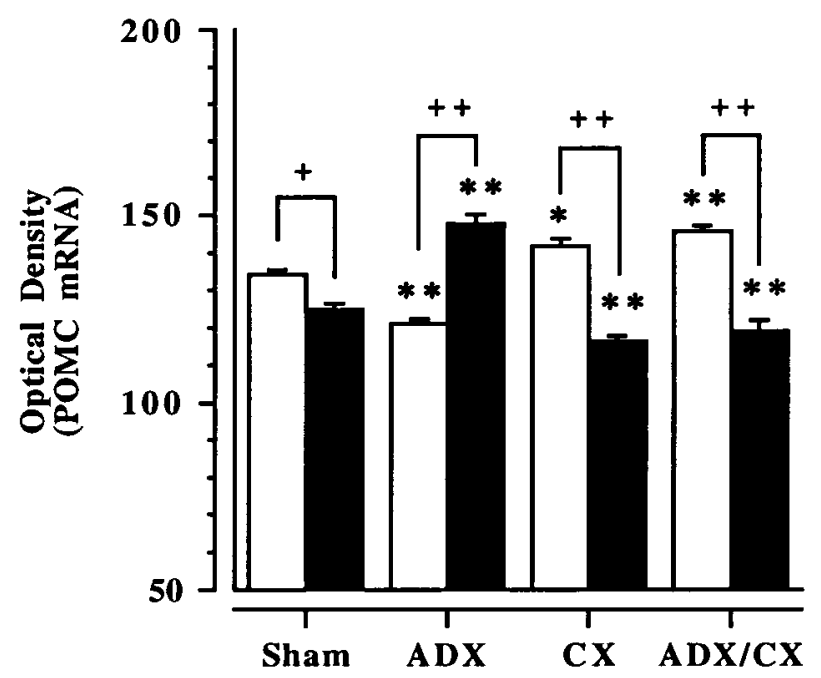

Figure 5 Effects of i.c.v. vehicle (open bars) or ODN (filled bars) injection on POMC mRNA expression in the IP lobe of shamoperated (Sham), ADX, CX and ADX/CX rats. Autoradiographic film was exposed for $5 \mathrm{~h}$ at $4{ }^{\circ} \mathrm{C}$. Results are expressed as the means \pm S.E.M. with $n=5$ in each groups of rats. ${ }^{*} P<0 \cdot 05$ and ${ }^{* *} P<0.01$ vs control sham-operated rats; $+P<0.05$ and $++P<0.01$ vs control rats in each group.

POMC mRNA levels. At the IP level, the involvement of the testis in the ODN POMC mRNA modulation is predominant in $\mathrm{ADX} / \mathrm{CX}$ rats, since $\mathrm{ODN}$ induced a decrease of the hybridization signal very similar to that observed in animals which were only CX.

GABAA receptors, which are oligomeric structures composed of multiple subunits that form chloride channels (MacDonald \& Olsen 1994), present some regional and functional heterogeneity (Sapp et al. 1992) that depend on the subunit composition of the receptor complex (MacDonald \& Angelotti 1993). Alterations in the gene expression of selective subunits seem to lead to changes in the density of GABAA receptor protein and the receptor subunit composition (Orchinik et al. 1994, 1995, Weiland \& Orchinik 1995). These might alter receptor sensitivity to activation by GABA or modulators such as BZD and thereby the pharmacological properties of the receptors (Orchinik et al. 1994, 1995, Weiland \& Orchinik 1995). Thus, several reports have shown some modifications in the GABAA receptor subunit composition after chronic stress or corticosterone exposure (Orchinik et al. 1995 and after progesterone injections (Weiland \& Orchinik 1995). Moreover ADX, by suppressing circulating glucocorticoids and progesterone (which in male rats originate from the adrenal cortex), might induce changes in receptor subunit composition of the GABAA receptor complex (Orchinik et al. 1994) and might then modify the ODN influence on POMC mRNA expression, at the hypothalamic level by decreasing CRH mRNA expression (Givalois et al. 1998a) and/or directly at the pituitary level (Louiset et al. 1992, Berman et al. 1994). In the IP, testicular influence on POMC mRNA expression induced by ODN does not seem to involve the tuberoinfundibular and tuberohypophyseal dopamine neurons, since gonadectomy did not alter dopamine synthesis and dopamine metabolism at these levels (Manzanares et al. 1992). A direct influence on the GABAA receptor complex is easier to envisage.

In conclusion, our data indicate that modifications in POMC mRNA expression in both the IP and AP induced by the endogenous BZD receptor ligand ODN are influenced by peripheral steroids, with a predominant influence of adrenals at the AP level and of the testis at the IP level. The mechanism(s) of action of these steroids appears more complex than a simple allosteric modulation of GABAA receptor, since some variations in the subunit composition of this receptor complex that alter its pharmacological properties have been described following variations in steroid concentrations. Other studies, such as the determination of the subunit composition of GABAA receptor after $\mathrm{ADX}$ and/or $\mathrm{CX}$ and evaluation of the effects of glucocorticoids, progesterone and testosterone, are required to establish the mechanism(s) of action of adrenal and gonadal factors involved in the regulation of POMC mRNA expression by ODN at the AP and IP levels. Such data should eventually contribute to a better understanding of the role of endozepines in the increased activity of the HPA axis observed in depressed patients (Roy et al. 1989).

\section{References}

Alho H, Costa E, Ferrero P, Fujimoto M, Cosenza-Murphy D \& Guidotti A 1985 Diazepam binding inhibitor: a neuropeptide located in selected neuronal populations of rat brain. Science 229 179-182.

Alho H, Bovolin P \& Slobodyansky E 1990 Diazepam binding inhibitor (DBI) processing: immunohistochemical studies in the rat brain. Neurochemical Research 15 209-216.

Assenmacher I, Barbanel G, Gaillet S, Givalois L, Ixart G, Malaval F, Mekaouche M, Siaud P \& Szafarczyk A 1995 Central regulation of ACTH release in stress. Annals of the New York Academy of Sciences $77141-54$.

Berman J, Roberts J \& Pritchett D 1994 Molecular and pharmacological characterization of GABAA receptors in the rat pituitary. Journal of Neurochemistry 63 10-22.

Björklund A, Moore R, Nobin A \& Stenevi U 1973 The organization of tubero-hypophyseal and reticulo-infundibular catecholamine neuron systems in the rat brain. Brain Research 51 171-179.

Chen C, Dionne F \& Roberts J 1983 Regulation of the proopiomelanocortin mRNA levels in rat pituitary by dopaminergic compounds. Proceedings of the National Academy of Sciences of the USA 80 2211-2215.

Costa E, Ahlo H, Santi R, Ferrero P \& Guidotti A 1986 Cotransmission of GABAergic synapses. In Progress in Brain Research, pp 343-355. Eds T Hokfelt, K Fuxe \& B Pernow. Amsterdam: Elsevier. 
Fenelon VS \& Herbison AE 1995 Characterisation of GABA(A) receptor gamma subunit expression by magnocellular neurones in rat hypothalamus. Molecular Brain Research 34 45-56.

Ferrero P, Guidotti A \& Conti-Tronconi B 1984 A brain octadecaneuropeptide generated by tryptic digestion of DBI (diazepam binding inhibitor) functions as a proconflict ligand of benzodiazepine recognition sites. Neuropharmacology 23 1359-1362.

Ferrero P, Santi MR, Conti-Tronconi B, Costa E \& Guidotti A 1986 Study of an octadecaneuropeptide derived from diazepam binding inhibitor (DBI): biological activity and presence in rat brain. Proceedings of the National Academy of Sciences of the USA 83 827-831.

Garcia-de-Yebenes E \& Pelletier G 1994 Negative regulation of proopiomelanocortin gene expression by GABAA receptor activation in the rat arcuate nucleus. Peptides 15 615-618.

Garcia-de-Yebenes E, Li S \& Pelletier G 1997 Regulation of proopiomelanocortin gene expression by endogenous ligands of the GABAA receptor complex as evaluated by in situ hybridization in the rat pars intermedia. Brain Research 750 277-284.

Givalois L, Li S \& Pelletier G 1997 Age-related decrease in the hypothalamic CRH mRNA expression is reduced by dehydroepiandrosterone (DHEA) treatment in male and female rats. Molecular Brain Research 48 107-114.

Givalois L, Grinevich V, Li S, Garcia-de-Yebenes E \& Pelletier G 1998a The octadecaneuropeptide-induced response of corticotropinreleasing hormone messenger RNA levels is mediated by GABAA receptors and modulated by endogenous steroids. Neuroscience $\mathbf{8 5}$ 557-567.

Givalois L, Li S \& Pelletier G 1998b Role of glucocorticoids in the modulation of corticotropin-releasing-hormone mRNA level by the endogenous benzodiazepine receptor ligand octadecaneuropeptide in rat brain. Neuroendocrinology $6898-104$.

Grigoriadis D, Pearsall D \& DeSouza E 1989 Effects of chronic antidepressant and benzodiazepine treatment on corticotropin-releasingfactor receptors in rat brain and pituitary. Neuropsychopharmacology 2 $53-60$.

Guidotti A, Forchetti CM, Corda MG, Konkel D, Bennett CD \& Costa E 1983 Isolation, characterization, and purification to homogeneity of an endogenous polypeptide with agonistic action on benzodiazepine receptors. Proceedings of the National Academy of Sciences of the USA 80 3531-3535.

Hollt V, Haarmann I, Seizinger B \& Herx A 1982 Chronic haloperidol treatment increases the levels of in vitro translatable messenger ribonucleic acid coding for the $\beta$-endorphin/ adrenocorticotropin precursor proopiomelanocortin in the pars intermedia of the rat pituitary. Endocrinology 110 1885-1891.

Jegou S, Tong Y, Blasquez C, Pelletier G \& Vaudry H 1991 Activation of the GABAA-benzodiazepine receptor complex inhibits proopiomelanocortin gene expression in the rat arcuate nucleus. Molecular and Cellular Neurosciences 2 440-445.

Kavaliers M \& Hirst M 1986 An octadecaneuropeptide (ODN) derived from diazepam binding inhibitor increases aggressive interactions in mice. Brain Research 383 343-349.

Li S \& Pelletier G 1995 Inhibitory effect of the potential endogenous benzodiazepine receptor ligand, octadecaneuropeptide (ODN), on gonadotropin-releasing hormone gene expression in the male rat brain. Neuroreport 6 1354-1356.

Li S \& Pelletier G 1996 Further studies on the mechanism of action of the endogenous benzodiazepine receptor ligand octadecaneuropeptide on gonadotropin-releasing hormone gene expression in the rat brain. Neuroendocrinology 64 79-84.

Li S, Givalois L \& Pelletier G 1997a Involvement of neurosteroids in the effect of the endogenous benzodiazepine receptor ligand octadecaneuropeptide (ODN) on gonadotropin-releasing hormone gene expression in rat brain. Journal of Neuroendocrinology 9 229-233.
Li S, Givalois L \& Pelletier G $1997 b$ Role of adrenal and gonadal steroids in the response of $\mathrm{GnRH}$ gene expression to the endogenous benzodiazepine receptor ligand octadecaneuropeptide (ODN) in male rat brain. Neuropeptides 31 463-468.

Loeffer J, Demeneix B, Pittius C, Kley N \& Haegele K 1986 GABA differentially regulates the gene expression of proopiomelanocortin in rat intermediate and anterior pituitary. Peptides 7 253-258.

Louiset E, Valentijin J, Vaudry H \& Cazin L 1992 Central-type benzodiazepines modulate GABAA receptor chloride channels in cultured pituitary melanotrophs. Molecular Brain Research 12 1-6.

Louiset E, Vaudry H \& Cazin L 1993 Allosteric modulation of the GABA-induced chloride current in frog melanotrophs. Annals of the New York Academy of Sciences 680 565-566.

MacDonald RL \& Angelotti TP 1993 Native and recombinant GABAA receptor channels. Cellular Physiology and Biochemistry 3 352-373.

MacDonald RL \& Olsen RW 1994 GABAA receptor channels. Annual Review of Neuroscience 17 569-602.

Malagon M, Vaudry H, Stuen FV, Pelletier G, Navarro FG \& Tonon MC 1993 Ontogeny of diazepam-binding inhibitor related peptides (endozepines) in the rat brain. Neuroscience $\mathbf{5 7} 777-786$.

Manzanares J, Toney T, Tian Y, Eaton M, Moore K \& Lookinglang K 1992 Sexual differences in the activity of periventricularhypophysial dopaminergic neurons in rats. Life Sciences $\mathbf{5 1}$ 995-1001.

Muller O \& Von Werder K 1991 Corticotropin-releasing hormone. In Brain Endocrinology, pp 351-375. Ed. M Motta. New York: Raven Press.

Orchinik M, Weiland NG \& McEwen BS 1994 Adrenalectomy selectively regulates GABAA receptor subunit expression in the hippocampus. Molecular and Cellular Neurosciences 5 451-458.

Orchinik M, Weiland NG \& McEwen BS 1995 Chronic exposure to stress levels of corticosterone alters GABAA receptor subunit mRNA levels in rat hippocampus. Molecular Brain Research 34 29-37.

Pelletier G 1993 Regulation of proopiomelanocortin gene expression in rat brain and pituitary as studied by in situ hybridization. Annals of the New York Academy of Sciences 680 246-259.

Rivest S \& Laflamme N 1995 Neuronal activity and neuropeptide gene transcription in the brains of immune-challenged rats. Journal of Neuroendocrinology 7 501-525.

Roy A, Pickar D, Gold P, Barbaccia M, Guidotti A, Costa E \& Linnoila M 1989 Diazepam-binding inhibitor and corticotropinreleasing hormone in cerebrospinal fluid. Acta Psychiatrica Scandinavica 80 287-291.

Saland LC, Gutierrez L, Kraner J \& Samora A 1988 Corticotropinreleasing factor (CRF) and neurotransmitters modulate melanotropic peptide release from rat neurointermediate pituitary in vitro. Neuropeptides 12 59-66.

Sapp DW, Witte U, Turner DM, Longoni B, Kokka N \& Olsen RW 1992 Regional variation in steroid anesthetic modulation of $\left[{ }^{35} \mathrm{~S}\right]$ TBPS binding to gamma-aminobutyric acid A receptors in rat brain. Journal of Pharmacology and Experimental Therapeutics 262 801-808.

Sawchenko PE 1987 Adrenalectomy-induced enhancement of CRF and vasopressin immunoreactivity in parvocellular neurosecretory neurons: anatomic, peptide, and steroid specificity. Journal of Neuroscience 7 1093-1106.

Spinedi E, Giacomini M, Jacquier MC \& Gaillard RC 1991 Changes in the hypothalamo-corticotrope axis after bilateral adrenalectomy: evidence for a median eminence site of glucocorticoid action. Neuroendocrinology 53 160-170.

Tong Y, Toranzo D \& Pelletier G 1991 Localization of diazepambinding inhibitor (DBI) mRNA in the rat brain by high resolution in situ hybridization. Neuropeptides 20 33-40.

Tonon MC, Adjeroud S, Lamacz M, Louiset E, Danger JM, Desrues L, Cazin L, Nicolas P \& Vaudry H 1989 Central-type benzodiazepines 
and the octadecaneuropeptide modulate the effects of GABA on the release of $\alpha$-melanocyte-stimulating hormone from frog neurointermediate lobe in vitro. Neuroscience 31 485-493.

Tonon MC, Desy L, Nicolas P, Vaudry H \& Pelletier G 1990 Immunocytochemical localization of the endogenous benzodiazepine ligand octadecaneuropeptide (ODN) in the rat brain. Neuropeptides 15 17-24.

Vale W, Spiers J, Rivier C \& Rivier J 1981 Characterization of a 41-residue ovine hypothalamic peptide that stimulates secretion of corticotropin and $\beta$ endorphin. Science 213 1394-1397.

Vuillez P, Perez S \& Stoeckel M 1987 Co-localization of GABA and thyroxine hydroxylase immunoreactivities in the axons innervating the neurointermediate lobe of the rat pituitary: an ultrastructural immunogold study. Brain Research 79 53-58.

Weiland NG \& Orchinik M 1995 Specific subunit mRNAs of the GABAA receptor are regulated by progesterone in subfields of the hippocampus. Molecular Brain Research 32 271-278.

Whitnall MH 1993 Regulation of the hypothalamic corticotropinreleasing hormone neurosecretory system. Progress in Neurobiology $\mathbf{4 0}$ 573-629.

Received 28 September 1998

Accepted 4 December 1998 